\title{
Russian-Speaking Immigrants in Post-Soviet Estonia: Towards Generation Fragmentation or Integration in Estonian Society
}

\author{
by Ellu Saar, Siim Krusell and Jelena Helemae \\ Tallinn University; Tallinn University; Tallinn University
}

Sociological Research Online, 22 (2), 13

$<\mathrm{http}: / /$ www.socresonline.org.uk/22/2/13.html>

DOI: $10.5153 /$ sro.4228

Received: 28 Jun 2016 | Accepted: 10 Mar 2017 I Published: 31 May 2017

\begin{abstract}
The disadvantages experienced by immigrants in education and labour markets have been of growing concern in many countries in recent years. However, little research has been undertaken on ethnic inequalities in labour markets in Eastern Europe, and especially in post-Soviet societies. This article considers the integration of the immigrant population into the labour market in post-Soviet Estonia, where the context and peculiarities of the arrived population are quite different from the assumptions of Western immigrant integration theories. The Russian-speaking population arrived in Estonia after World War II as internal migrants, because Estonia was part of the Soviet Union. A remarkably high proportion of them were well educated. After Estonia regained its independence in 1991, the context of integration changed radically, and the legal status of internal Soviet Union migrants was redefined. To account for these societal and political changes, we suggest making an analytical distinction between generations of immigrants in a demographic sense (being born in Estonia) and an integrational sense (becoming an integral part of the host society, in the labour market - having more similar patterns to those of the native population in the context of labour market outcomes). This distinction impacts differently on different age cohorts and we analysed outcomes of labour market integration alongside both nativity generations and age cohorts. Our analysis based on the 2011-2013 Labour Force Surveys shows that, while in most Western countries there are tendencies of convergence between natives and second-generation immigrants regarding structural integration, in Estonia the dynamics are different. The net disadvantage of young second-generation immigrants relative to their Estonian counterparts is either more pronounced compared to the disadvantage of their 'parents' age cohort relative to their Estonian peers (with regard to the risks of unemployment or chances of obtaining a high occupational position) or becoming less pronounced, but only for the highly educated portion of second generations (in terms of selfassessed over-education).
\end{abstract}

Keywords: Structural Integration, Immigrants, First and Second Generation, Post-Soviet Estonia

\section{Introduction}

The disadvantages experienced by immigrants in education and labour markets have been a matter of growing concern in many countries in recent years. Second-generation immigrants (that is, the children of immigrants, born in the host society) make up a growing proportion of the population in the US and in many Western European countries (Waters et al. 2012). Their successful integration into the labour market is a very real problem. There has been much research about first- and second-generation immigrants over the last 15 years (Crul \& Vermeulen 2003; Heath \& Cheung 2007b; Heath et al. 2008; Kogan 2006; Lessard-Phillips et al. 2012; Phalet \& Heath 2010; Portes \& Rumbaut 2001; Westin 2003; Silberman et al. 2007; Thomson \& Crul 2007). One of the most basic questions that this research has considered is whether the labour market opportunities of immigrants and natives converge or diverge over time. Here the "generation" is the main temporal measure of change, being approached as the "ancestral distance from the point of arrival in a society" (Alba 1988), so that second-generation refers to the native-born children of immigrants. 
theoretical approaches: segmented assimilation theory, new assimilation theory and integration context theory. The first two theories were developed for the North American context. The central idea of segmented assimilation theory (Portes \& Rumbaut 2001; Portes \& Zhou 1993) is that there is more than one way to assimilate into American society. The new assimilation theory assumes that the dominant stream remains "straight-line assimilation" (Alba \& Nee 2003). Both theories have also been quite influential in Europe. Both American theories also emphasise the importance of societal and local contexts. A comparison of outcomes in the secondgeneration across different European countries allowed Crul and Schneider (2010) to formulate the comparative integration context theory. This theory argues that the participation of immigrants in the host society is strongly dependent on institutional arrangements, for example, in education and labour markets. However, empirical studies in Europe mainly indicate that most second-generation immigrants are better educated and find more skilled employment than their parents (Heath \& Cheung 2007a; Kogan 2007; Van Tubergen 2006) and, thus, that general trends show upward social mobility across generations.

1.3 The limitations of these studies are related to a tacit assumption about the rather stable context of integration, so that there is no need for any temporal measure of its change. This insensitivity towards contextual change might be partly explained by the selection of countries involved in comparisons (i.e. those assumed to have problems with the integration of second-generation immigrants). Compared to Western countries, much less research has been undertaken about ethnic inequalities in the labour market in Eastern Europe, and especially in post-Soviet societies with their large shares of population with migrant backgrounds and the substantial change of legal status of this population after the demise of the Soviet Union (see for Latvia, Hazans 2011; for Estonia, Vetik \& Helemäe 2011b; for Estonia and Latvia, Aasland \& Fløtten 2001, Lindemann 2013; for the Baltics, Hazans et al. 2008).

1.4 This study considers the integration of the immigrant population into the labour market in post-Soviet Estonia. Immigrant integration in Estonia is distinct in several ways. First, in terms of the magnitude and dynamics of the process: about one sixth of the current Estonian population is foreign-born; this percentage, $17 \%$, is higher than the $13 \%$ for the United States (OECD 2013, 25). Ethnic Russians form the biggest minority group, comprising about $25 \%$ of the total population according to the 2011 Census (Census Snapshots: 46 ).

1.5 Second, another peculiarity was that a remarkably high proportion of the immigrants to Soviet Estonia were well educated. They were usually employed in professional and skilled occupations and they did not experience any status change due to migration (Lindemann 2011).

1.6 Third, most importantly, the patterns of migration to Estonia differed significantly from classic labour migration in many Western countries. The Russian-speaking immigrants arrived in Estonia after World War II, when the country was part of the Soviet Union. By the time of their arrival, they were internal migrants from a legal perspective. In Estonia, first-generation migrants did not have to compete with local inhabitants, as was the case in Western European countries: the labour market bureaucratic segmentation (enterprises with a Russianspeaking labour force were controlled by central Soviet ministries, while local Estonian firms were governed by Estonian ministries employing ethnic Estonians) coincided with ethnic segmentation. Under the state command economy, there was no room for any kind of ethnic economy as in the USA (Vöörmann and Helemäe 2003).

1.7 Fourth, the Estonian case is about the abrupt change in the very nature of the integrational context. The nation state model based on the legal continuity principle, and therefore, including a redefinition of the legal status of post-war migrants from the Soviet Union, became the basis for many new social and political institutions and policies (Pettai \& Hallik 2002). The extremely neo-liberal character of the market reforms and the ethnic nation state ideology created a new kind of opportunity structure, contributing to the emergence of new economic and ethnic inequalities (Vetik \& Helemäe 2011b). This means that the integration of first-generation and secondgeneration Russian-speaking immigrants in Estonia should be very different and much more complex (particularly due to the crucial change in opportunity structures) compared to what research has revealed for immigration to Western Europe.

1.8 Our main aim was to investigate whether there was a convergence between Russian-speaking immigrants and natives in labour market outcomes. We followed the usual approach for testing Western integration theories, i.e. evaluate whether convergence or divergence of labour market outcomes between immigrants' generations and natives has taken place. However, to take changes in integration context into account, we suggested complimenting the "ancestral" or nativity temporal dimension (time since arrival in the host country measured in respective generations), which is usual for ethnic studies, with temporal dimensions used in life course research, i.e. distinguishing between processes attributable to ageing, historical period and 
birth cohorts. Based on this analytical distinction between generations in both the demographic sense (nativity) and integrational sense, we define "integrational" as only the youngest portion of those Russian-speakers who could be characterized as second-generation immigrants according to the nativity approach. Comparison of this "integrational" (25-34 year olds) second generation with the first generation cohort of their parents age, and also the comparison of these immigration cohorts with their native counterparts, allows us to draw change-sensitive conclusions about the direction of integrational processes in the Estonian labour market. This analytical distinction allows us to apply theories developed and tested for Western countries to this context, where the abrupt changes in the opportunities structures of ethnic groups had taken place. We concentrated on labour market integration features, such as unemployment, occupational status and perceived over-education. We used data from the 2011, 2012 and 2013 Estonian Labour Force Survey (LFS).

\section{Theoretical approaches to the definition of immigrant generations in Western countries}

2.1 All theoretical approaches dealing with generational differences emanate from the assumption that the first generation of migrants was negatively selected in terms of human capital. This is the case in most European, as well as other immigration, countries, e.g. the United States, Canada and Australia. In much of Western Europe guest worker programmes were introduced in the 1950s and 1960s. Migrant workers were originally recruited from among the least educated and most impoverished rural segments of the sending countries (Alba \& Waters 2011). This led to the establishment of large, relatively low-educated and poorly qualified migrant communities. Therefore, the disadvantages of the first-generation immigrants may be explained by their lack of human capital relevant in the country of their destination. Besides having a relatively low level of education they may also not have been fluent in the language of their destination country (Chiswick 2002). Foreign educational credentials and foreign work experience, which may not have the same value on the labour market in their country of destination, might also have been problems (Friedberg 2000). In addition, migrants will often be at a disadvantage because the process of migration itself tends to be disruptive. These kinds of factors may lead to less favourable labour market opportunities for first-generation immigrants compared to local inhabitants (Heath \& Cheung 2007a).

Theoretical approaches differ in the ways the opportunities of second- and succeeding generations are estimated. Classical assimilation theory argues that the individual paths of second-generations, gradually leaving behind their ethnic identities, enable advancement in the labour market. In particular, assimilation is considered to be part of the process of upward mobility across immigrant generations (Gordon 1964).

Segmented assimilation theory (Portes \& Zhou 1993) emerged as an alternative to this model in the 1990s. This theory postulates that the children of immigrants are likely to follow one of three paths. The first is the classic pattern of straight-line assimilation into mainstream society across generations. The second is downward assimilation into a permanently impoverished population at the bottom of society. The third is assimilation into their own community in the form of occupying ethnic economic niches that might contribute to upward mobility.

2.3 Some authors suggest that the segmented assimilation theory is not applicable in the European context as the theory is very dependent on particular structural features of the US economy and society (Phalet \& Heath 2011; Thomson \& Crul 2007). They argue that downward assimilation in Europe cannot possibly exist, as there is no underclass in European inner cities. Another argument against downward mobility is that, in Europe, many labour migrant groups enter society right at the bottom, with nowhere to go but up (Heath et al. 2008). Others conclude that the "segmented-assimilation phenomenon" exists in European countries, where there is a risk of downward assimilation, but no evidence of downward assimilation (Silberman et al. 2007). However, empirical studies seem to confirm the importance of diversification and polarization in the second-generation (Crul \& Heering 2008). Vermeulen (2012) assumes that although segmented assimilation theory is as applicable to Europe as to the US, it is not clear how much of the cross-national differences, in the way that immigrants and their children integrate, can be explained by it.

2.4 In response to the segmented assimilation approach, Alba and Nee (2003) formulated a new version of straight-line assimilation for post-1965 immigrants (new assimilation theory). They predict that most members of the second-generation will experience gradually increasing social integration and upward mobility. In contrast to the segmented assimilation theory, they find little support for downward assimilation or the advantages of dense ethnic networks. Thomson and Crul (2007) also conclude that upward mobility through ethnic cohesion remains a limited phenomenon in the European context. They argue that American theories have generally focused too much on the immigrant group and underestimated the importance of the national contexts. They proposed the comparative integration context theory, which suggests that differences in social and political contexts are very important for the social integration of the second-generation (see also Crul \& Schneider 2010). 
Comparative integration studies on second-generation immigrants provided theory with the important insights into the country-specificity of the integrational context, while less attention had been paid to the peculiarities of context that might be brought about by temporal changes. Heath et al. (2008) suggest that because characteristics of societies often come in packages, the importance of particular features of the national context for integration of the second generation of immigrants might be best approached on the basis of natural experiments (e.g., Germany's reforms of its citizenship legislation). Reitz and Somerville (2004) also stress the importance of institutional and structural change for the integration of the second generation. In 1988 Alba suggested that, in addition to generation, a time line that "merits at least equal attention is that of birth cohorts, with its emphasis on historical shifts in life chances" (1988: 214). In this way he proposed to apply to immigrants' integration studies a distinction usually made in life course research, which is between the temporal dimensions of ageing, historical period and birth cohorts. Recently, the idea of using birth cohort in conjunction with generation to reveal processes of ethnic change has won more support (e.g., Alba et al. 2014; Bohrt \& Itzigsohn 2015; Waters \& Jimenez 2005). This conceptualization of time is well suited to capture temporal change both in the integration context as well as within the immigrant group.

The Estonian context of abrupt societal changes and the post-factum legal redefinition of the status of post-war newcomers might provide valuable insights into the issue of the integration of second-generation immigrants.

\section{The Estonian context}

3.1 Before World War II (WWII) Estonia was ethnically relatively homogeneous (Estonians comprised 97 per cent of the population in 1940). The greatest flows of immigrants into Estonia - up to 45,000 people a year (Kulu 2001 ) - took place immediately after the war. In the period 1945-1989 the number of Russian speakers in Estonia grew from 26,000 to 602,000 (Vetik 1993). This dramatic demographic shift, and the resulting fundamental change in the ethnic composition of the population, was attributed to the colonial policies of the Soviet Union, which aimed to reconstruct Estonia - both economically and socially - as an integral part of the Soviet Union (Kuzio 2002; Mettam \& Williams 2001). The main aim was the integration of incorporated territories into the Soviet Union (Hallik 2002). Thus, the current integration context has certain features of the post-colonial condition. However, this condition differs from the Western European context, where immigrants arrived in the host countries from the ex-colonies. In Estonia, the direction of migration was in the opposite direction. Also, whereas in Western European countries the foreign-born proportion of the population increased in the past decade, Estonia is the exception (OECD 2013: 24).

In the 1960s, immigration was promoted and controlled via organized labour recruitment. The initial flow of Russian language immigrants served to shape a party and state elite dedicated to imperialist policies and to establishing a loyal bureaucracy in Estonia. Among the immigrants to Estonia were numerous bureaucrats and high-ranking officials brought in to oversee the implementation of Soviet policies, in both the state administration and state enterprises (Kulu 2001). Russians were the largest ethnic group among immigrants. Despite having varied ethnic backgrounds, more than half of the non-Russian immigrants arriving in Estonia spoke Russian as their mother tongue (e.g. Ukrainian, Belorussian). By now Russian-speakers formed $92 \%$ of the immigrant population. Many Russians migrated to Estonia immediately after finishing either their vocational or higher education (Saar \& Titma 1992). The census data from 1989 shows that the average education level of the Russian-speaking population residing in Estonia was significantly higher than the average education level of Estonians (Lindemann \& Saar 2012). There was also only a little difference in the occupational structure of the Estonian and Russian population: in $1989,26 \%$ of Estonians and $22 \%$ of minority groups worked as managers or professionals (Lindemann 2011). Thus, contrary to the usual situation in Western countries, first-generation immigrants in Estonia were not negatively selected.

3.3 Moreover, as Estonia after WWII was part of the Soviet Union, Russian-speaking people by the time of their arrival were not immigrants in legal sense, but internal migrants. They were ascribed the status of firstgeneration immigrants after the fall of the Soviet Union, which makes them quite different to first-generation immigrants in Western countries. They also considered themselves to be members of the majority nation of the Soviet Union and were merely moving from one part of the Soviet Union to another (Pettai \& Hallik 2002). They were not obliged by either official policies or institutions to consider themselves as immigrants. Indeed, Estonian language requirements were not officially stated in the labour market, and educational credentials achieved outside Estonia were relevant in Estonia (Vetik \& Helemäe 2011a). 
1992). The official policies and institutions supported the integration of newcomers into the economy in a way that resulted in the ethnic segmentation of Estonian society (Vöörmann \& Helemäe 2003). The economies of the Soviet Union's Republics were split into so-called all-union and local segments. Employment followed the network lines of the formal bureaucracy: some enterprises were subject to all-union branch ministries, while local ministries ruled others. Russian-speaking newcomers were mainly employed in the all-union Russian-language enterprises, which operated mainly in Russian. Estonians worked mostly in the enterprises controlled by Estonian authorities, but were also overrepresented in the culture and education sectors.

Ethnic segmentation emerged, not only in the economic sphere, but also in education (two parallel ethnic-language school systems within a highly centralized education system with a highly standardised curriculum), in the regional sphere, in neighbourhoods (Ojamäe \& Paadam 2011) and social networks (which were enterprise-centred). Russian-speaking migrants remained culturally separated from Estonian society; they did not engage with local people and had marginal contacts with the Estonian language (some residential areas, educational institutions and industries functioned exclusively in the Russian language) (Rannut 2008). Therefore, the integration context of the first-generation Russian-speaking minority immigrants in Estonia was completely different to typical Western immigrant countries.

3.6 After Estonia regained its independence in 1991, the context of integration changed radically. The collapse of the Soviet Union and the marketization of the Estonian economy drastically changed the political, social and economic hierarchy of ethnic groups (Aasland \& Fløtten 2001). The Estonian economy was reoriented towards Western markets and it ceased to be part of the Soviet economy both in the bureaucratic and purely economic sense. As a result, structural changes first of all hit manufacturing, the main basis of the Russian segment of the economy (agriculture, being an Estonian sector of the economy, was also negatively influenced).

3.7 The societal transition for Russians was not just about moving from a planned economy to a free market, but about moving from being a privileged national ethnic group within a large "empire" to an ethnic minority within a new nation state (Kennedy 2002). The transition to a market economy took place at the same time as the creation of a new nation-state model and redefinition of legal status of post WWII migrants (Vetik \& Helemäe 2011b). The Citizenship Law adopted in 1992 was exclusive, in the sense that citizenship was granted only to those residents and their descendants who were citizens of Estonia before the Soviet occupation. The Law requires two years' residency before a person is entitled to apply for citizenship and it restricts certain categories of people from gaining citizenship (for example, Soviet military officers). The Law also requires knowledge of the Estonian language, and this effectively resulted in the majority of the Russian-speaking population living in Estonia becoming stateless (Vetik \& Kionka 1996). From a legal standpoint this meant that the Russian-speaking population who themselves or whose ancestors had arrived to Estonia since WWII was redefined as immigrants.

3.8 Vetik and Helemäe (2011a) consider that first- and second-generation Russian-speaking migrants in Estonia represent an atypical category of "semi-immigrants": they can be regarded as immigrants in some respects, but non-immigrants in others. They have acquired an "in-between" status involuntarily, as a result of the drawing of new state boundaries between Estonia and Russia when Estonia regained independence, and by the nationalising policies redrawing previous social and political boundaries in Estonian society. The nationalising policies tend to emphasise that the Russian-speaking population are immigrants in Estonia.

3.9 The post-factum redefinition of the legal status of Russian-speakers had important socio-economic consequences for the whole ethnic group of Russians, contributing to their moving into an inferior status in the labour market. With the restoration of the Estonian Republic, legal requirements for accessing many labour market segments were established. For example, proficiency in the Estonian language and Estonian citizenship were required for many labour market segments, especially for higher status occupational positions. The difficulties that first-generation immigrants often have to face in Western labour markets became real for many Russian-speaking migrants in Estonia, regardless of their immigrant generation. In most Western countries there are tendencies of convergence between natives and second-generation immigrants in terms of structural integration. Contrary to that, we suggest that in ethnically segmented Estonia post-Soviet institutional and structural changes have led to an inferior socio-economic status for all immigrants. In newly independent Estonia this new status made the situation of all immigrants (regardless of their immigration generation) comparable to that of the first generation immigrants in Western countries.

\section{Methodological approach}

4.1 To assess whether the labour market outcomes of immigrants and natives converge or diverge under the circumstances described above, a more subtle approach to the conceptualization of temporal changes is 
needed. To compliment the usual criteria for the ethnic studies "ancestral"/nativity generation dimension (time since arrival to host country measured in respective generations) we suggested including temporal dimensions used in life course research, i.e. to distinguish between processes attributable to ageing, historical period and birth cohorts. This allows us to make analytical distinctions between immigrant generations in the demographic sense and in the substantive, i.e. integrational, sense. As a result of the redefinition of the legal status of previously internal Soviet immigrants and their children, after the restoration of the Estonian state, all of them (even those born in Estonia) found themselves in the situation of first-generation immigrants. Only the youngest of the demographic second-generation, i.e. those who were socialized in an independent Estonian Republic, might be considered second-generation immigrants in the same sense as used in Western ethnic studies. In this way we adapted theories developed and tested for Western countries to the Estonian context of the abrupt changes in the hierarchy of ethnic groups. This also allowed us to take into account the impact of societal processes, such as educational expansion and structural changes in the labour market, etc.

As longitudinal data does not exist, we used the cross-sectional comparison of age cohorts belonging to different nativity generations to provide valuable insights into the process of integration. In Estonia we proposed making the distinction between generations of immigrants in the demographic versus the integrational sense because of the deep and abrupt changes in the integrational context. So, in terms of integration, the notion of second-generation can only be applied to the second-generation of Russian speakers, who were socialised and attained their education in the restored Estonian Republic. To separate the effect of the changed integrational context (i.e. the changed hierarchy of ethnic groups due to the restoration of the Estonian Republic) from the effect of immigrant status in the demographic sense (being born in Estonia), and also to take account of the peculiarities of labour market outcomes related to life course (ageing), we distinguished between age cohorts and also between first- and second-generation immigrants (see Table 1).

Table 1. Differentiation of Russian-speakers according to immigrant status and age cohorts

\begin{tabular}{|l|l|l|l|}
\hline \multirow{2}{*}{$\begin{array}{l}\text { Immigrant status (in } \\
\text { demographic sense) }\end{array}$} & 25-34 & $35-49$ & $50-59$ \\
\cline { 2 - 4 } & $\begin{array}{l}\text { Estonian Republic's } \\
\text { cohort }\end{array}$ & \multicolumn{2}{|c|}{ Age group } \\
\hline First generation & $\begin{array}{l}\text { First generation, } \\
\text { "Estonian Republic's" } \\
\text { cohort }\end{array}$ & $\begin{array}{l}\text { First generation, } \\
\text { "Winners" cohort }\end{array}$ & $\begin{array}{l}\text { First generation, } \\
\text { "Older", i.e. cohort of } \\
\text { parents of "Estonian } \\
\text { Republic's" cohort } \\
\text { [SU1] }\end{array}$ \\
\hline Second generation & $\begin{array}{l}\text { Second generation, } \\
\text { "Estonian Republic's" } \\
\text { cohort [ER2] }\end{array}$ & $\begin{array}{l}\text { Second generation, } \\
\text { "Winners" cohort }\end{array}$ & $\begin{array}{l}\text { Second generation, } \\
\text { "Older", i.e. cohort of } \\
\text { parents of "Estonian } \\
\text { Republic's" cohort }\end{array}$ \\
\hline
\end{tabular}

The 25-34 year olds (the "Estonian Republic" age cohort) accumulated their human capital and started their work careers in the independent Estonian Republic, while the two "Soviet" age cohorts (of 35-49 years and 50-59 years) had done this in Soviet Estonia. The younger "Soviet" age cohort is often called the "Winners generation" - its representatives were at the best age to take advantage of the opportunities opened up by societal change. Those in the 50-59 year old age group also participated actively in societal change, but by the time of survey (2011-2013) they were approaching the end of their work careers. At the same time the first generation immigrants aged 50-59 might be included as the parents of the second-generation immigrants in the 25-34 years old group. Our suggestion is that this latter group, the 25-34 year olds, is the only second-generation group of immigrants in an integrational (as distinct from demographic) sense.

4.4 Previous research shows that the dissimilarity between young second-generation Russians and Estonians, in terms of education, has increased compared to their parents' generation (Lindemann \& Saar 2012). Data from the Estonian Labour Force Survey of 2011-2103 also show that the expansion of higher education 
favoured the youngest generation of Estonians, but not their Russian-speaking counterparts belonging to the second-generation of immigrants (see Appendix 1): the proportion of people with higher education is significantly lower in our main cohort of interest compared with Estonians of the same age. Also, this gap is significantly higher than the gap between their parents' cohort (i.e. first-generation Russian-speaking immigrants) and their Estonian counterparts. This indicates that, in case of Russian-speaking immigrants in Estonia, it is this historical break (i.e., the contextual effect) - the restoration of the Estonian Republic and the redefinition of their group status - that matters most (not just the immigrant status effect in the demographic sense, i.e. being personally a first- or second-generation immigrant). We suggest that given the high impact of education on labour market status, this educational disadvantage structures the relative (compared to Estonians) chances for the labour market success or failure of young second-generation Russian-speaking immigrants. To what extent this disadvantage might be mitigated due to success in other (social and cultural) aspects of integration of secondgeneration immigrants into the new societal context is a somewhat empirical question.

\title{
Data and methods
}

5.1 The data source for our analysis was the Estonian Labour Force Survey (LFS). The LFS is a sample survey, with data collected from individuals and it provides an extensive overview of labour market indicators. Pooled data from 2011, 2012 and 2013 was used, and the sample size of immigrants (30,337 respondents) allowed a fairly thorough comparison between the first and second-generation. As mentioned above the use of the concepts of the first- and second-generation immigrants in the Estonian context is not clear in a substantive sense. However, in our empirical analysis we concentrated on the first- and second-generation in a demographic sense. First-generation immigrants are those who actually immigrated (those whose parents were not born in Estonia). Second-generation immigrants are those who were born in Estonia, but whose parents were born abroad. To identify so-called Russian-speakers, i.e. East-Slavs versus Estonians as the titular nation, we used data on ethnic self-identification. Thus, our population of interest was differentiated according to Immigrant status variable: 1 - First-Generation immigrants (Russians, Ukrainians and Belarusians), 2 - Second-Generation immigrants (Russians, Ukrainians and Belarusians), 3 - Estonians.

5.2 As the flow of immigration to Estonia since beginning of the 1990s has almost stopped, the firstgeneration is overrepresented by elderly people. To minimise the impact of the age composition of immigrant generations and that of the particularities of labour market entrance and exit, we focused on the prime age group 25-59 in our analysis. We further differentiated between age groups 25-34, 35-49 and 50-59 years. The first group were educated and integrated into the labour market in independent Estonia, while the older two groups were educated and integrated into the labour market during the Soviet period.

5.3 The dependent variables characterising the structural integration in this analysis were unemployment risk, the probability of having a managerial or professional position and the mismatch between work and education. Unemployment 1 - status of unemployed according to International Labour Office (ILO) definition, 0 - employed. Attainment of managerial or professional status 1- manager or professional (1 or 2 according to the International Standard Classification of Occupations (ISCO) 08 1-digit code), 0 - other occupations.

Mismatch between job and education (over-education) was measured on the basis of the workers assessment of the education needed for the job performed 1 - the education required for current job is lower than the higher level of attained education, 0 - the education required for current job is not lower than the higher level of attained education.

\section{Explanatory variables}

\begin{abstract}
Gender 1 - Males, 2 - Females Education 1 - General secondary, 2 - Primary or basic, 3 - Vocational secondary, 4 - Specialized secondary, 5 - Higher education Residence 1 - Harju County, 2 - Ida-Viru County, 3 - Other counties Occupational group 1 - Managers, 2 - Professionals, 3 - Semi-professionals, 4 - Clerks, 5 - Service workers, 6 Agricultural workers, 7 - Industrial skilled workers, 8 - Unskilled workers Economic sector 1 - Agriculture, hunting and forestry, fishing, 2 - Mining and quarrying, manufacturing, electricity, gas and water supply, 3 - Construction, 4 Wholesale and retail trade, hotels and restaurants, transport, storage and communication, 5 - Financial intermediation, real estate, renting and business activities, 6 - Public administration and defence, education, health and social work.
\end{abstract}

\section{Strategy}

5.4 To test existing theories about labour market integration of immigrants, i.e. convergence or divergence between generations of immigrants and the titular ethnic group, we carried out the analysis according to both aspects of the notion of immigrant integration: first we analysed the labour market outcomes of immigrant 
generations in a demographic sense and second, in an integrational sense. To approach the integrational aspect of immigrant integration, we focused on the series of comparisons combining age cohorts and nativity generations (see Table 2). Our main cohort of interest was the second-generation in the integrational sense, i.e. second-generation immigrants of age 25-34 years who were born in the Estonian Republic (ER2).

Table 2. Strategy of comparisons to reveal the impact of integrational aspect of immigrant generation on labor market outcomes

\begin{tabular}{|c|c|}
\hline Concept & $\begin{array}{l}\text { Operationalization of integrational aspect of immigrant } \\
\text { generation }\end{array}$ \\
\hline \multicolumn{2}{|c|}{ a. Generations of immigrants } \\
\hline Second generation & Second generation immigrants, 25-34 years old [ER2 ] \\
\hline First generation & First generation immigrants, $50-59$ years old [SU1] \\
\hline \multicolumn{2}{|c|}{ b. First generation of immigrants versus natives } \\
\hline First generation & First generation immigrants, $50-59$ years old [SU1] \\
\hline Natives & $50-59$ years old Estonians \\
\hline \multicolumn{2}{|c|}{ c. Second generation of immigrants versus natives } \\
\hline Second generation & Second generation immigrants, 25-34 years old [ER2] \\
\hline Native & $25-34$ years old Estonians \\
\hline \multicolumn{2}{|c|}{ d. Control for integrational aspect: comparison between generations of natives } \\
\hline Young generation & 25-34 years old Estonians \\
\hline Their parents generation & $50-59$ years old Estonians \\
\hline
\end{tabular}

These comparisons were made in two steps. The first step was based on a comparison of the distributions. The second step was the regression analyses to evaluate gross and net disadvantages. Heath and Cheung (2007a) suggest that when evaluating ethnic minority disadvantages in education and labour markets it is important to distinguish between the distinct concepts: (1) gross disadvantage, and (2) net disadvantage. We followed the logic of Heath and Cheung's analysis and incorporated variables (see Appendices 1, 2 and 3) sequentially into the models in order to separate the gross and net disadvantages. Using logistic regression analysis, we started with a model for the gross effect of the immigrant (demographic) generation, where only the immigrant generation is entered as a predictor. In the next model we added age group, i.e. birth cohorts that integrated into the labour market (experienced initial advantages or disadvantages) under different societal contexts. In subsequent models, we tested the roles of gender and human capital (Model 3) and structural indicators (place of residence, economic sector and occupational group- Model 4) as explanatory variables, to find the net effect of the immigrant (demographic) generation. In order to discern the peculiarities of labour market outcomes for the only age fraction of the demographic second-generation that might also be considered to be an integrational second-generation in the Estonian Republic, we added the interaction terms between age and immigrant generation into Model (5).

\section{Results}


Unemployment, occupational group and self-perceived over-education of first- and secondgeneration immigrants

Higher education has been an important factor in reducing the risk of unemployment and giving better occupational opportunities in Estonia. Previous research showed that in 2011-2013 in Estonia, the differences between Estonians and the immigrants of both generations and age cohorts remained. Our main cohort of interest (second-generation immigrants born in the Estonian Republic among 25-34 year olds, henceforth ER2) experienced a higher risk of unemployment compared to both first-generation immigrants in their parents' age cohort of 50-59 year olds, (henceforth SU1) and Estonians of the same age. The gap between the ER2 cohort and its Estonian age-cohort counterpart is even wider than the gap between SU1 and its Estonian age-cohort counterpart (Table 3).

Table 3. Employment status of titular Estonians and immigrant population aged 25-59, in Estonia, 2011-13, $\%$

\begin{tabular}{|c|c|c|c|c|c|c|c|c|c|}
\hline \multirow[t]{2}{*}{$\begin{array}{l}\text { Employment } \\
\text { status }\end{array}$} & \multicolumn{3}{|c|}{$\begin{array}{l}\text { First generation } \\
\text { immigrants }\end{array}$} & \multicolumn{3}{|c|}{$\begin{array}{l}\text { Second generation } \\
\text { immigrants }\end{array}$} & \multicolumn{3}{|c|}{ Estonians } \\
\hline & $\begin{array}{l}25- \\
34\end{array}$ & $\begin{array}{l}35- \\
49\end{array}$ & $\begin{array}{l}50-59 \\
{[\mathrm{SU1}]}\end{array}$ & $\begin{array}{l}25-34 \\
\text { [ER2] }\end{array}$ & $\begin{array}{l}35- \\
49\end{array}$ & $\begin{array}{l}50- \\
59\end{array}$ & $\begin{array}{l}25- \\
34\end{array}$ & $35-49$ & $50-59$ \\
\hline Employed & 68 & 78 & 72 & 71 & 77 & 70 & 76 & 85 & 77 \\
\hline Unemployed & 18 & 15 & 11 & 17 & 15 & 11 & 7 & 6 & 7 \\
\hline Inactive & 14 & 8 & 17 & 11 & 9 & 20 & 17 & 9 & 16 \\
\hline Total & 181 & 996 & 1751 & 671 & 1348 & 756 & 6024 & 11679 & 6956 \\
\hline
\end{tabular}

Source: Own calculations based on Estonian Labor Force Surveys 2011-13.

Notice: Immigrants consist Russians, Ukrainians, Byelorussians.

Table 4 shows that ER2, despite a lower level of education than SU1, was more successful in attaining the high-status occupational positions of managers and professionals. However, ER2's educational disadvantage relative to Estonians of the same age brought about occupational disadvantages as well: only a fifth of ER2 was employed as a manager or professional, while a third of their Estonian counterparts attained these positions. The gap between our main age-cohort of interest, ER2, and its Estonian counterpart was about the same (only slightly closer) compared with SU1 and its Estonian age-cohort counterpart. Given the lower educational level of ER2 compared with SU1, this suggests the more successful application of education in the labour market by the younger generation.

Table 4. Occupational position of titular Estonians and immigrant population aged 25-59, in Estonia, 2011-13, $\%$

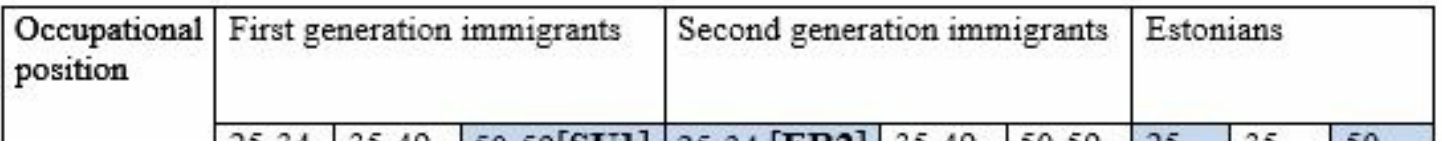




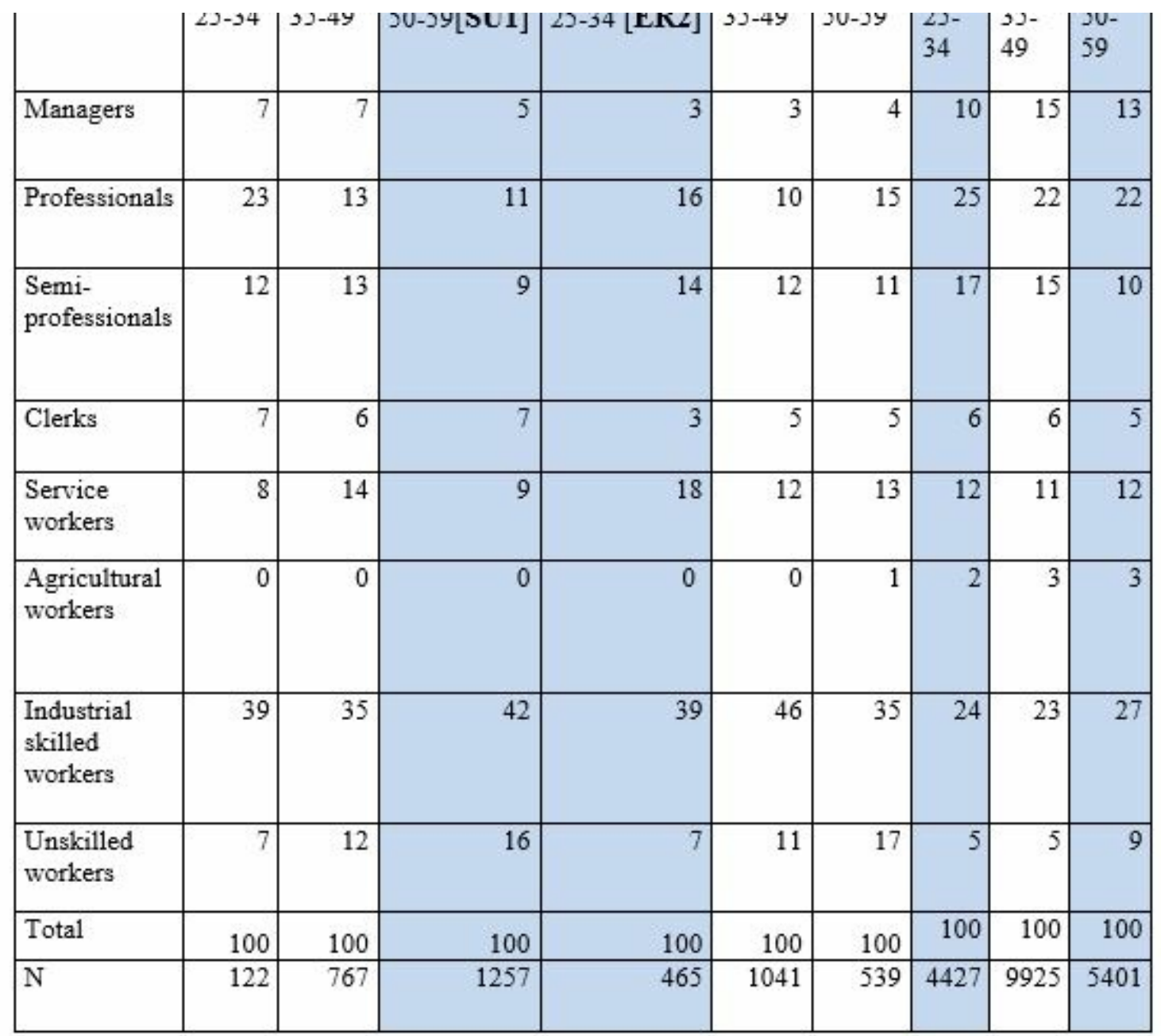

Source: Own calculations based on Estonian Labor Force Surveys 2011-13.

Notice: Immigrants consist Russians, Ukrainians, Byelorussians.

6.3 The data presented in Table 5 (comparison of age-cohorts in terms of self-assessed match between job and education) support this suggestion: compared with other groups of immigrants with higher education, representatives of our main age-cohort of interest, ER2, are the least concerned about over-education. However, there are still more people with higher education who self-assess that their education is too high for the job they perform.

Table 5. Self-assessed match between job and education of titular Estonians and immigrant population with higher education, in Estonia, 2011-13, \%

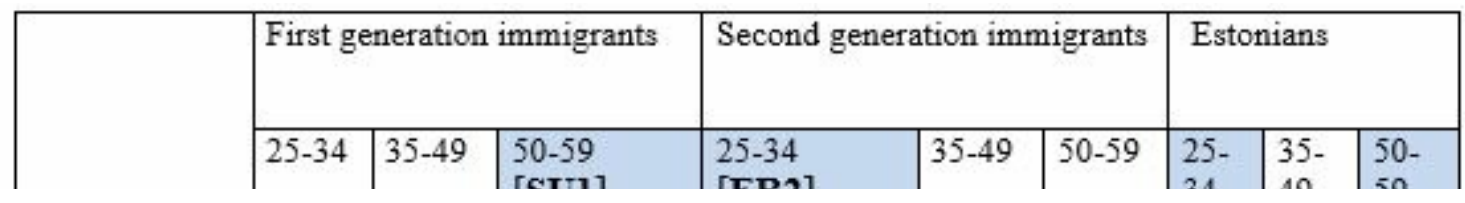




\begin{tabular}{|c|c|c|c|c|c|c|c|c|c|}
\hline & & & [001] & [DN] ] & & & 34 & 47 & בע \\
\hline Match & 78 & 76 & 73 & 85 & 80 & 74 & 87 & 91 & 90 \\
\hline Undereducated & 3 & 1 & 1 & 2 & 2 & 1 & 4 & 4 & 1 \\
\hline Overeducated & 19 & 23 & 27 & 12 & 18 & 25 & 8 & 5 & 9 \\
\hline Total & & & & & & & 100 & 100 & 100 \\
\hline & 100 & 100 & 100 & 100 & 100 & 100 & & & \\
\hline $\mathrm{N}$ & 126 & 767 & 1257 & 465 & 1041 & 539 & 4474 & 9961 & 5410 \\
\hline
\end{tabular}

Source: Own calculations based on Estonian Labor Force Surveys 2011-13.

Notice: Immigrants consist Russians, Ukrainians, Byelorussians.

Gross and net disadvantages of immigrant generations

6.4 We proceeded with the logistic regression analysis to distinguish between the two concepts elaborated by Heath and Cheung (2007a), gross and net disadvantages. When evaluating ethnic minority disadvantage in labour markets the gross difference can be examined by comparing ethnic groups with each other, the net disadvantages are identified when additional variables are added to the model. Odds ratios from logistic regression models were used to identify the gross and net disadvantages of first- and second-generation Russian-speaking immigrants compared to the Estonians (see Appendices B, C and D).

6.5 We started with a comparison of the labour market position of demographic immigrant generations. In terms of the gross evaluation of unemployment risks, both first-generation and second-generation immigrants have a higher risk of becoming unemployed than Estonians (Appendix B). There is no evidence that the gross disadvantage of the second-generation is less pronounced than that of the first-generation (Model 1). Neither the addition of individual (age, education and gender - Models 2 and 3) nor structural variables (Model 4) changed this relationship significantly.

6.6 When estimating the probability of securing a managerial or professional position (see Appendix C) the gross difference between Estonians and the first-generation immigrants was more than two times in favour of Estonians (Model 1), while the gross difference between second-generation immigrants and Estonians was three times in favour of Estonians. Thus, second-generation immigrants had an even smaller chance of securing a managerial or professional position compared to first-generation immigrants. Model 2 with the additional age variable produced very similar results. However, adding gender and education as the independent variables (Model 3) brought about a significant change: the net advantage of Estonians over the first-generation (over 3 times) turned out to be bigger than the net advantage over the second generation (about 2.7 times). Thus, contrary to the gross disadvantage, the second-generation turned out to have a net advantage over the firstgeneration. This result indicates that second-generation immigrants are more successful compared with firstgeneration immigrants in securing positional returns to their education. When economic sector and region were added as independent variables into Model 4, the relative advantage of Estonians over both generation of immigrants of being professionals or managers turned out to be even bigger.

6.7 Returns to education are also reflected in the perceived mismatch between job and education. Appendix D shows that where models for people with higher education only are presented, both net and gross probabilities are higher compared to those of Estonians. Immigrants of both generations perceived their jobs to require lower education levels than they have. The gross disadvantage of first-generation immigrants compared to Estonians is more than six times, while that of the second-generation is more than three times, indicating, once again, that second-generation immigrants are more successful than first-generation immigrants in securing positional returns to their education. As to net disadvantage, Models 2 and 3 indicate the low impact of age and gender, while structural location matters (see Model 4). However, even within a similar structural location the risk of perceiving over-education was lower for Estonians: double compared with the first-generation immigrants and 1.7 times compared with the second-generation immigrants. Large gross differences between the self-assessed over-education of first- and second-generation immigrants are largely based on the advantageous (compared to the first-generation) structural location of second-generation immigrants.

6.8 To go beyond the study of demographic immigrant generations, i.e. to explore the peculiarities of the labour market integration of 25-34 year old second-generation immigrants in the Estonian Republic's cohort 
(ER2) as the only substantive second-generation in the Estonian context, probabilities were calculated on the basis of models with interactions of demographic immigrant generation and age cohort (Models 5 in Appendices 1-3). Figures 1-3 show the net disadvantage of both generations of immigrants compared with Estonians in terms of all explored indicators. Figure 1 shows that representatives of our main age-cohort of interest, ER2, experience a higher unemployment risk compared both with their parents' age cohort SU1 and their Estonian counterparts. Moreover, the disadvantage of the ER2 age cohort relative to its Estonian counterpart was slightly greater compared with the disadvantage of its parents' age cohort (SU1) relative to its Estonian counterpart, indicating the process of divergence between immigrants and Estonians.

Figure 1. Unemployment risk of Estonians and immigrant population by age groups, in Estonia, logistic regression analysis, odds ratios

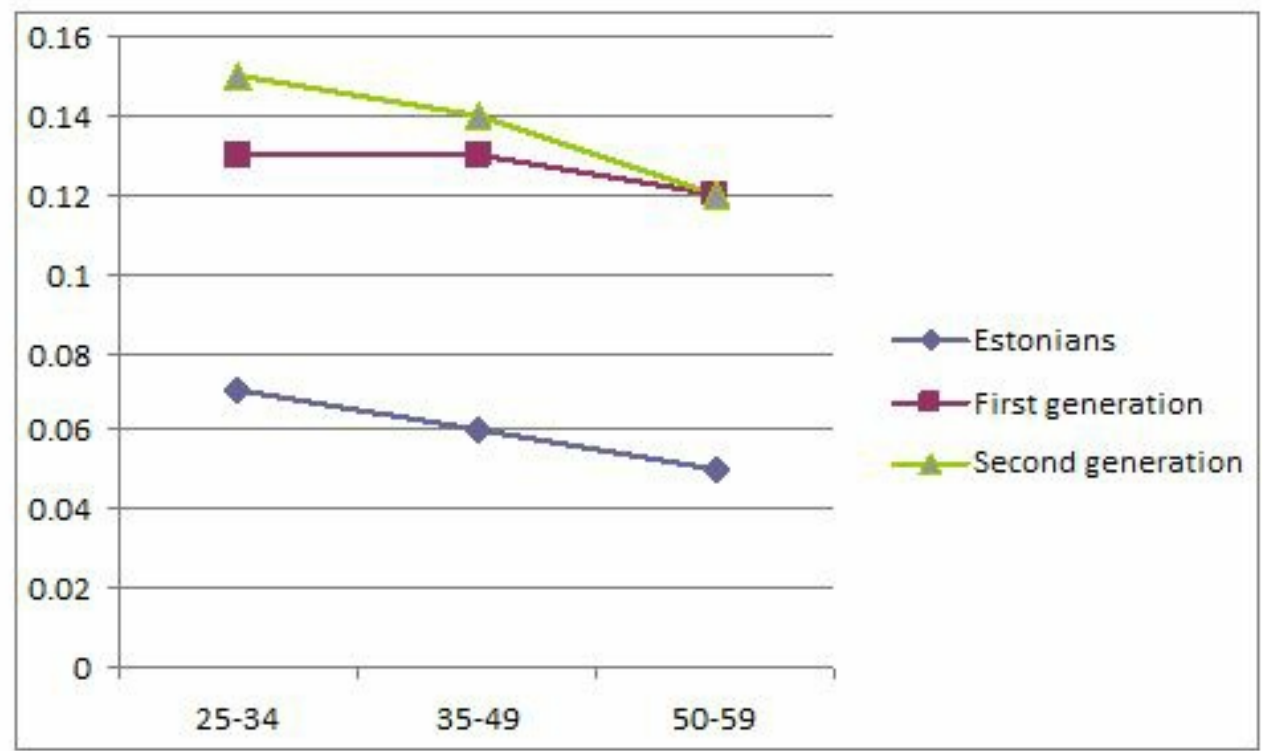

Source: Own calculations based on Estonian Labor Force Surveys 2011-13.

6.9 Figure 2 shows that the chance of our main cohort of interest (ER2) of attaining high occupational positions are slightly lower than the 50-59 year old first-generation immigrants (SU1) and that there is a substantial net disadvantage relative to Estonians of the same age. Also, just as with unemployment risk, the widening of the net disadvantage of immigrants relative to Estonians shows the process of divergence between immigrants and Estonians. 
Figure 2. Chances of Estonians and immigrant population to attain high occupational position (managers or professionals) by age groups, in Estonia, logistic regression analysis, odds ratios

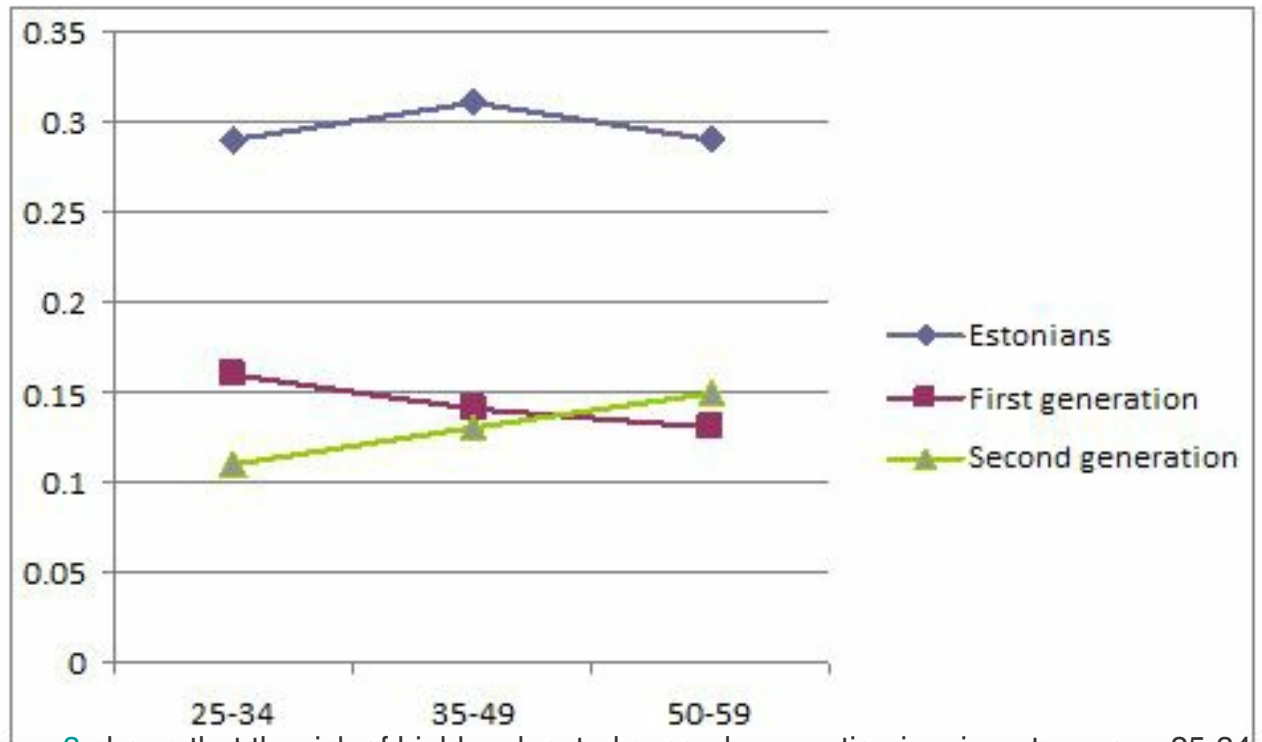

6.10 Figure 3 shows that the risk of highly educated second-generation immigrants among 25-34 year olds

(ER2) assessing themselves as overeducated is lower than their parents' (SU1) cohort and substantially higher

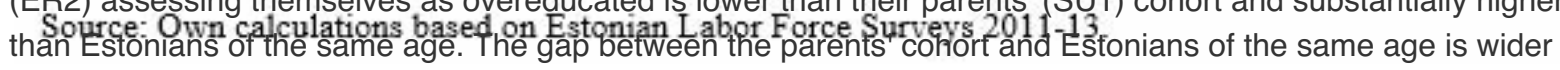
than the gap between our main cohort of interest and its Estonian counterpart indicates that a convergence between the highly educated immigrant population and Estonians is taking place. Taken together with the results presented above, this also refers to the polarisation within our main cohort of interest (ER2), i.e. the secondgeneration immigrants in the Estonian Republic's cohort. Those with higher education within this cohort (ER2) tend to converge with their Estonian counterparts, but there is a process of divergence in the chances of obtaining higher education itself. Moreover, this convergence occurred against the backdrop of the huge net disadvantage of the referent (SU1) cohort of 50-59 year old first-generation immigrants relative to their Estonian counterparts. Our main suggestion was that given the high impact of education on labour market status, educational disadvantage structures the relative (compared to Estonians) chances for labour market success or failure of young second-generation Russian-speaking immigrants (ER2). Our analysis shows that the educational disadvantage of young second-generation Russian-speaking immigrants (ER2) relative to both their parents' cohort (SU1) and its Estonian counterpart does matter and contributes to their internal polarisation in terms of labour market integration. So, those with higher education tend to converge with their Estonian counterparts, and those with lower levels of education diverge from them. 


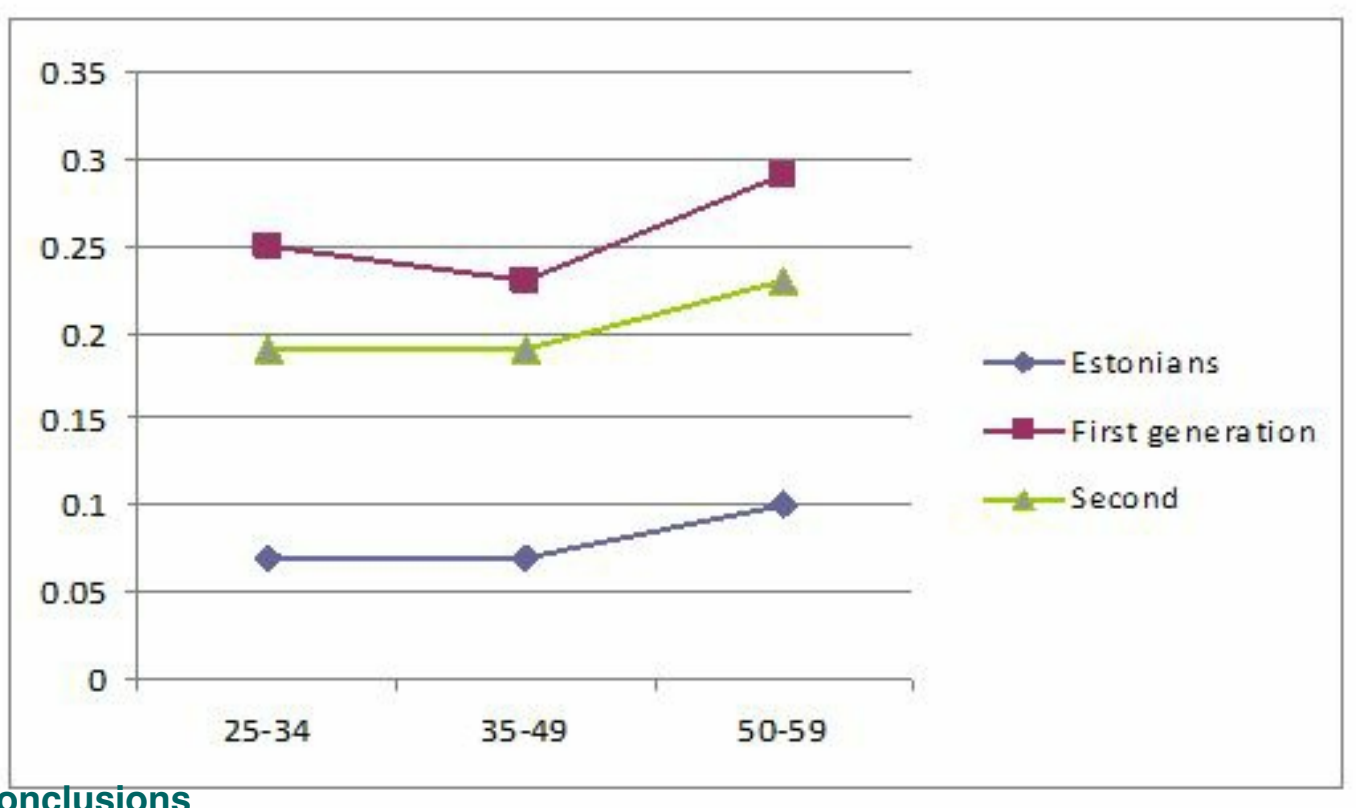

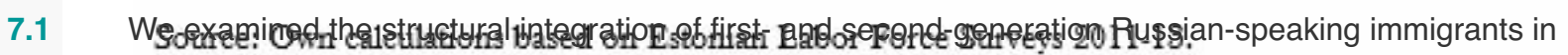

Estonia. While it is possible to separate the two generations of immigrants in the demographic sense in Estonia, it is problematic to use these concepts to describe their integration outcomes. The background of first-generation immigrants and their status during the Soviet period was very different to first-generation immigrants in Western countries, and they were not even immigrants in a legal sense. Changes in Estonian society in the 1990s profoundly altered the integration context, brought about the downward group social mobility of non-Estonians, particularly Russian-speakers, and thus put both immigrant generations into a radically new situation. We agree with Vetik and Helemäe (2011a) that both generations of immigrants could be considered as "semi-immigrants" and propose making a distinction between generations of immigrants in the demographic versus the integrational sense because of the abrupt change of the integrational context in Estonia. To develop this approach further, we suggest applying the notion of second-generation in terms of integration only to the second-generation of Russian speakers, who were socialised and attained their education in the restored Estonian Republic. This means that at the same time that we applied the notion of (nativity) generation in conjunction with age cohort.

The main aim of this paper was to compare the labour market integration of two generations of immigrants and their labour market outcomes with those of the titular ethnic group. We carried out analyses based on both - demographic and integrational - aspects of the immigrant generations. To make a distinction between demographic and integrational aspects of immigrant generations we used an ordinary temporal measure of integration - nativity generation along with the age cohorts. We considered 25-34 year old (in the demographic sense) second-generation immigrants as the only second-generation group of immigrants in the integrational sense in contemporary Estonia. First generation Russian-speakers of 50-59 years old were considered as the parents' generation of second-generation immigrants. Comparisons with Estonians were also made according to age groups. We applied this analytical distinction to account for the social and political changes that brought about the redefinition of the legal status of Russian-speaking immigrants in Estonia.

7.3 While in most traditional immigration countries there are tendencies of convergence between natives and second-generation immigrants regarding structural integration, compared to their parents (Thomson \& Crul 2007), in Estonia the dynamics are more complex. Our analysis showed that the labour market integration of young second-generation immigrants is significantly influenced by their lack of educational upward mobility and the smaller chance that they have to undertake higher education compared with their counterparts among Estonians. Thus, in terms of unemployment risk, our analysis showed the net disadvantage of young secondgeneration immigrants (our main cohort of interest) relative to both their parents' age cohort (50-59 year old firstgeneration immigrants) as well as their Estonian counterparts. Moreover, our approach - a combination of generational and age group analyses - allowed us to show an even more serious problem with labour market integration of the young second-generation. The net disadvantage of young second-generation immigrants relative to their Estonian counterparts in terms of risks of unemployment is more pronounced than the disadvantage of their parents' age cohort relative to their Estonian peers. 
The young second-generation do have some net advantage over the first-generation: where they have a similar level of education they have a somewhat higher chance of securing a managerial or professional position compared to the first-generation, which indicates that they reap a higher positional return to higher education. However, just as with unemployment risk, the net disadvantage of young second-generation immigrants relative to their Estonian counterparts in terms of their chance to hold a high occupational position is more pronounced compared to the disadvantage of their parents' age cohort relative to their Estonian peers. Thus, in Estonia, being a second-generation immigrant, socialised and educated in the independent Estonian Republic, proved to be a distinct disadvantage compared with the titular ethnic group, so that the distance between young people (second-generation immigrants vis a vis their Estonian peers) has widened compared with the distance between their parents' first-generation immigrants and parents' Estonian peers. This disadvantage starts in the educational system (with lower chances of attaining higher education) and becomes especially pronounced in the labour market, revealing itself in the disadvantage in reaping returns from education investments.

At the same time the analysis of self-assessed over-education shows that when higher education is attained, the distance between the young group of the second-generation and their Estonian counterparts is less than that between their parents' age cohort and older Estonians. These results are indicative of internal differentiation within the young second-generation, which is in line with Western accounts of the heterogeneity of second-generation immigrants (see Crul \& Heering 2008). The successful (highly educated) part of the group tends to fit into the logic of integration as there is growing parity between successive generations and natives, while the distance between the whole young second-generation and Estonian counterparts is increasing compared to that of their parents' age cohorts.

Recent research on ethnic groups in European countries has drawn upon the theory of segmented assimilation. Particular focus has been on the theory's two alternative modes of incorporation: downward assimilation and upward mobility through ethnic cohesion (Thompson \& Crul 2007). Previous research on young Russians in post-soviet Estonia, based only on the demographic dimension of integration, indicates that the Estonian case is rather different, in that it is indicative of the downward assimilation of the second-generation compared to the first-generation (Lindemann \& Saar 2011). However, given that a remarkably high proportion of the Russian-speaking immigrants who arrived in Estonia after WWII were highly educated, and given their successful structural integration, the downward assimilation of the second generation had not been to the lowest rungs of society. Previous research also shows that segmentation into ethnic communities does not contribute to upward mobility, but rather it turns into a mobility trap in terms of education and labour market success (Lindemann 2013). There is also no analogue in Estonia to downward assimilation or upward mobility through inclusion in ethnic niches (Vöörmann \& Helemäe 2003).

Our analysis, based on the usual notions of immigrant generations for Western ethnic studies, applied an analytical distinction between the demographic and integrational aspects of immigrant generations and also a more sophisticated approach to time measurement was used, i.e. the notions of nativity generation and age cohort were used in conjunction. This allowed us to evaluate the steps of immigrant integration as age-specific processes of convergence and divergence between immigrant generations and their native counterparts more thoroughly. Our analysis showed that in the contemporary Estonian labour market the growing distance between successive immigrant generations (young Russian-speakers socialized in the Estonian Republic and their parents' age cohort) and their native counterparts coincide with the growing parity between them. In this way, the Estonian case supports the suggestion about the heterogeneity of second-generation immigrants (cf. Crul \& Heering 2008).

Making a distinction between the different time dimensions of the process of integration, and in this way between demographic and integrational immigrant generations, allowed us to take into account the abrupt changes in the context of immigrant integration in Estonia. We believe that our methodological approach can inform future research in other post-Soviet societies, particularly with regard to the labour market integration of immigrants from different age cohorts. Previous findings indicate that the outcomes for the Russian-speaking second-generation vary, even in the post-Soviet societies that are hosts to large Russian-speaking minority groups (Lindemann 2013). Our conclusion is that in addition to the present institutional and structural contexts, the historical context pertaining to the time when the immigrants moved to their destination country is also very important, as is the context before they migrated, because there are continuities between the past and present (see also Foner \& Lucassen 2012; Lindemann 2013). 
for Western countries as well, particularly in exploring how significant change due to events (e.g., changes in immigration legislation) or large-scale processes (e.g. expansion of higher education) influences the integration of different age cohorts.

\section{Appendix 1}

APPENDIX A. Levels of education of natives (ethnic Estonians) and immigrant population aged 25-59, in Estonia, 2011-13, \%

\begin{tabular}{|c|c|c|c|c|c|c|c|c|c|}
\hline \multirow{2}{*}{$\begin{array}{l}\text { Level of } \\
\text { education }\end{array}$} & \multicolumn{3}{|c|}{ First generation immigrants } & \multicolumn{3}{|c|}{ Second generation immigrants } & \multicolumn{3}{|c|}{ Estonians } \\
\hline & $25-34$ & $35-49$ & $50-59[\mathrm{SU1}]$ & $25-34[$ ER2] & $35-49$ & $50-59$ & $\begin{array}{l}25- \\
34\end{array}$ & $35-49$ & $\begin{array}{l}50- \\
59\end{array}$ \\
\hline $\begin{array}{l}\text { Primary or } \\
\text { basic }\end{array}$ & 11 & 6 & 7 & 13 & 8 & 6 & 15 & 11 & 15 \\
\hline $\begin{array}{l}\text { General } \\
\text { secondary }\end{array}$ & 13 & 16 & 16 & 15 & 20 & 21 & 19 & 21 & 21 \\
\hline $\begin{array}{l}\text { Vocational } \\
\text { secondary }\end{array}$ & 16 & 26 & 20 & 35 & 29 & 19 & 15 & 17 & 13 \\
\hline $\begin{array}{l}\text { Specialized } \\
\text { secondary }\end{array}$ & 15 & 25 & 33 & 12 & 28 & 30 & 11 & 20 & 23 \\
\hline Higher & 46 & 28 & 25 & 25 & 15 & 24 & 39 & 31 & 27 \\
\hline Total & 100 & 100 & 100 & 100 & 100 & 100 & 100 & 100 & 100 \\
\hline $\mathrm{N}$ & 181 & 984 & 1747 & 666 & 1344 & 756 & 6024 & 11679 & 6956 \\
\hline
\end{tabular}

Source: Own calculations based on Estonian Labor Force Surveys 2011-13.

Notice: Immigrants consist Russians, Ukrainians, Byelorussians. 
Appendix B. Logistic regression analysis, unemployment risk, odds ratios

\begin{tabular}{|c|c|c|c|c|c|}
\hline & Model 1 & Model 2 & Model 3 & Model 4 & Model 5 \\
\hline \multicolumn{6}{|l|}{ Natives (Estonians - reference group) } \\
\hline First generation immigrants & $2.310^{* * *}$ & $2.459^{* * *}$ & $2.648^{* * *}$ & $2.253^{* * *}$ & $3.700^{* * 8}$ \\
\hline Second generation immigrants & $2.556^{* * *}$ & $2.568^{* * *}$ & $2.604^{* * *}$ & $2.246^{* * *}$ & $2.362^{* * 8}$ \\
\hline \multicolumn{6}{|l|}{ Age group } \\
\hline \multicolumn{6}{|l|}{$25-34$ (reference group) } \\
\hline $35-49$ & & $.818^{* * *}$ & $.862^{* * *}$ & $.862^{* * *}$ & $.908 * * *$ \\
\hline $50-59$ & & $.816^{* * *}$ & $.847^{* * *}$ & $.817^{* * *}$ & $.953 * * 8$ \\
\hline \multicolumn{6}{|l|}{ Men (reference group) } \\
\hline Women & & & $1.117^{* * *}$ & $1.264^{* * *}$ & $1.260 * * 8$ \\
\hline \multicolumn{6}{|l|}{ Educational level } \\
\hline \multicolumn{6}{|l|}{ Primary or basic (reference group) } \\
\hline General secondary & & & $.487^{* * *}$ & $.573^{* * *}$ & $.573^{* * 8}$ \\
\hline Vocational secondary & & & $.420^{* * *}$ & $.472^{* * *}$ & $.472^{* * *}$ \\
\hline Specialized secondary & & & $.343 * * *$ & $.440^{* * *}$ & $.446^{* * *}$ \\
\hline Higher & & & $.234^{* * *}$ & $-424^{* * *}$ & $.424 * * *$ \\
\hline \multicolumn{6}{|l|}{ Place of residence } \\
\hline \multicolumn{6}{|l|}{ Harju county (reference group) } \\
\hline Ida-Viru county & & & & $1.335^{* * *}$ & $1.349 * * 8$ \\
\hline Other counties & & & & $1.164^{* * *}$ & $1.159 * * 8$ \\
\hline \multicolumn{6}{|l|}{ Occupational group } \\
\hline \multicolumn{6}{|l|}{ Managers (reference group) } \\
\hline Professionals & & & & $1.386^{* * *}$ & $1.389 * * 8$ \\
\hline Semiprofessionals & & & & $1.366^{* * *}$ & $1.377^{* * 8}$ \\
\hline Clerks & & & & $2.061^{* * *}$ & $2.086^{* * *}$ \\
\hline Service workers & & & & $2.093^{* * *}$ & $2.115^{* * *}$ \\
\hline Agricultural workers & & & & $1.396^{* * *}$ & $1.425^{* * 8}$ \\
\hline Industrial skilled workers & & & & $2.018^{* * *}$ & $2.033^{* * 8}$ \\
\hline Unskilled workers & & & & $3.244^{* * *}$ & $3.295 * * 8$ \\
\hline \multicolumn{6}{|l|}{ Economic sector } \\
\hline Agriculture (reference group) & & & & $1.174^{* * *}$ & $1.189 * * 8$ \\
\hline Mining, manufacturing & & & & $1.893^{* * *}$ & $1.939 * * *$ \\
\hline Construction & & & & $1.058^{* * *}$ & $1.078 * * *$ \\
\hline $\begin{array}{l}\text { Wholesale and retail trade; hotels and } \\
\text { restaurants; transport, storage and } \\
\text { communication }\end{array}$ & & & & 1.181 & 1.212 \\
\hline Financial intermediation, business activities & & & & $.699 * * *$ & $.705^{* * 8}$ \\
\hline $\begin{array}{l}\text { Public administration, education, health and } \\
\text { social work }\end{array}$ & & & & $1.174^{* * *}$ & $1.189 * * *$ \\
\hline \multicolumn{6}{|l|}{ Interaction age $x$ immigrant generation } \\
\hline $35-49 \mathrm{x}$ first generation & & & & & $.579 * * 8$ \\
\hline $35-49 \mathrm{x}$ second generation & & & & & .971 \\
\hline $50-59 \mathrm{x}$ first generation [SU1st_50-59] & & & & & $.482 * * 8$ \\
\hline $50-59 \mathrm{x}$ second generation & & & & & $.800 * * 8$ \\
\hline Constant & $.072^{* * *}$ & $.080^{* * *}$ & $.179^{* * *}$ & $.062^{* * *}$ & $.058 * * 8$ \\
\hline$R$ square & .03 & .03 & .07 & .09 & .09 \\
\hline
\end{tabular}

Source: Own calculations based on Estonian Labor Force Survey 2011-13.

*** significant at level .001 
Appendix C. Logistic regression analysis, attainment of high (managerial or professional) occupational position, odds ratios

\begin{tabular}{|c|c|c|c|c|c|}
\hline & Model 1 & Model 2 & Model 3 & Model 4 & Model 5 \\
\hline \multicolumn{6}{|l|}{ Natives (Estonians - reference group) } \\
\hline First generation immigrants & $.380 * * *$ & $.381^{* * *}$ & $.319^{* * *}$ & $.306^{* * *}$ & $.446^{* * *}$ \\
\hline Second generation immigrants & $.337 * * *$ & $.336^{* * *}$ & $.369 * * *$ & $.348^{* * *}$ & $.467 * * 8$ \\
\hline \multicolumn{6}{|l|}{ Age group } \\
\hline \multicolumn{6}{|l|}{$25-34$ (reference group) } \\
\hline $35-49$ & & $1.107 * * *$ & $1.398^{* * *}$ & $1.490^{* * *}$ & $1.594^{* * *}$ \\
\hline $50-59$ & & .998 & $1.238^{* * *}$ & $1.316^{* * *}$ & $1.412^{* * *}$ \\
\hline \multicolumn{6}{|l|}{ Gender } \\
\hline \multicolumn{6}{|l|}{ Men (reference group) } \\
\hline Women & & & $.826^{* * *}$ & $.635^{* * *}$ & $.637^{* * 8}$ \\
\hline \multicolumn{6}{|l|}{ Educational level } \\
\hline \multicolumn{6}{|l|}{ Primary or basic (reference group) } \\
\hline General secondary & & & $4.706^{* * *}$ & $3.741^{* * *}$ & $3.748^{* * 8}$ \\
\hline Vocational secondary & & & $3.038^{* * *}$ & $2.617 * * *$ & $2.616^{* * 8}$ \\
\hline Specialized secondary & & & $6.399^{* * *}$ & $5.078^{* * *}$ & $5.099 * * 8$ \\
\hline Higher & & & $42.197^{* * *}$ & $26.012^{* * *}$ & $26.147^{* * 8}$ \\
\hline \multicolumn{6}{|l|}{ Place of residence } \\
\hline \multicolumn{6}{|l|}{ Harju county (reference group) } \\
\hline Ida-Viru county & & & & $.812^{8 * *}$ & $.829 * * 8$ \\
\hline Other counties & & & & $.664^{* * *}$ & $.659 * * 8$ \\
\hline \multicolumn{6}{|l|}{ Economic sector } \\
\hline \multicolumn{6}{|l|}{ Agriculture (reference group) } \\
\hline Mining, manufacturing & & & & $1.838 * * *$ & $1.848 * * 8$ \\
\hline Construction & & & & $1.670^{8 * *}$ & $1.691^{* * 8}$ \\
\hline $\begin{array}{l}\text { Wholesale and retail trade; hotels and } \\
\text { restaurants; transport, storage and } \\
\text { communication }\end{array}$ & & & & $2.598^{* * *}$ & $2.628 * * 8$ \\
\hline Financial intermediation, business activities & & & & $4.177^{* * *}$ & $4.222^{* * 8}$ \\
\hline $\begin{array}{l}\text { Public administration, education, health and } \\
\text { social work }\end{array}$ & & & & $5.224^{* * *}$ & $5.248 * * 8$ \\
\hline \multicolumn{6}{|l|}{ Interaction age $x$ immigrant generation } \\
\hline $35-49 \mathrm{x}$ first generation & & & & & $.655^{* * 8}$ \\
\hline $35-49 \mathrm{x}$ second generation & & & & & $.530^{* * *}$ \\
\hline $50-59 \mathrm{x}$ first generation [SU1st_50-59] & & & & & $.587^{* * 8}$ \\
\hline $50-59 \mathrm{x}$ second generation & & & & & $.684 * * 8$ \\
\hline Constant & $.424 * * *$ & $-411^{* * *}$ & $.038^{* * *}$ & $.023^{* * *}$ & $.022 * * 8$ \\
\hline$R$ square & .04 & .04 & .34 & .37 & .37 \\
\hline
\end{tabular}

Source: Own calculations based on Estonian Labor Force Survey 2011-13.

$* * *$ significant at level .001 
Appendix D. Logistic regression analysis, self-assessed over-education, only persons with higher education

\begin{tabular}{|c|c|c|c|c|c|}
\hline & Model 1 & Model 2 & Model 3 & Model 4 & Model 5 \\
\hline \multicolumn{6}{|l|}{ Immigrant (demographic) generation } \\
\hline \multicolumn{6}{|l|}{ Natives (Estonians - reference group) } \\
\hline First generation immigrants & $6.191^{* * *}$ & $6.048^{* * *}$ & $6.051^{* * *}$ & $2.058 * * 8$ & $1.960^{* * *}$ \\
\hline Second generation immigrants & $3.337^{* * *}$ & $3.298^{* * *}$ & $3.300 * * *$ & $1.734^{* * 8}$ & $1.775^{* * *}$ \\
\hline \multicolumn{6}{|l|}{ Age group } \\
\hline \multicolumn{6}{|l|}{$25-34$ (reference group) } \\
\hline $35-49$ & & $.752^{* * *}$ & $.754^{* * *}$ & $.855^{* * 8}$ & $.720^{* * *}$ \\
\hline $50-59$ & & $1.062 * *$ & $1.063^{* *}$ & $1.122^{* * 8}$ & $1.290^{* * *}$ \\
\hline \multicolumn{6}{|l|}{ Gender } \\
\hline \multicolumn{6}{|l|}{ Men (reference group) } \\
\hline Women & & & 974 & $1.295 * * 8$ & $1.279 * * *$ \\
\hline \multicolumn{6}{|l|}{ Place of residence } \\
\hline \multicolumn{6}{|l|}{ Harju county (reference group) } \\
\hline Ida-Viru county & & & & $1.108 * 8$ & $1.122^{* *}$ \\
\hline Other counties & & & & $.947^{*}$ & .954 \\
\hline \multicolumn{6}{|l|}{ Occupational group } \\
\hline \multicolumn{6}{|l|}{ Managers (reference group) } \\
\hline Professionals & & & & $2.165^{* * 8}$ & $2.165 * 8 *$ \\
\hline Semiprofessionals & & & & $5.974^{* * 8}$ & $6.019 * 8 *$ \\
\hline Clerks & & & & $20.374^{* * 8}$ & $20.513^{* 8 *}$ \\
\hline Service workers & & & & $23.369 * * 8$ & $23.382 * 8 *$ \\
\hline Agricultural workers & & & & $3.044^{* * *}$ & $3.019^{* * *}$ \\
\hline Industrial skilled workers & & & & $43.912^{* * *}$ & $43.279^{* * *}$ \\
\hline Unskilled workers & & & & $262.098 * * 8$ & $265.699 * * *$ \\
\hline \multicolumn{6}{|l|}{ Economic sector } \\
\hline \multicolumn{6}{|l|}{ Agriculture (reference group) } \\
\hline Mining, manufacturing & & & & $.819^{*}$ & $.812^{*}$ \\
\hline Construction & & & & $.372 * * 8$ & $.362^{* * *}$ \\
\hline $\begin{array}{l}\text { Wholesale and retail trade; hotels and } \\
\text { restaurants; transport, storage and } \\
\text { communication }\end{array}$ & & & & $.636^{* * 8}$ & $.616^{* 8 *}$ \\
\hline Financial intermediation, business activities & & & & $.630 * * 8$ & $.616^{* * *}$ \\
\hline $\begin{array}{l}\text { Public administration, education, health and } \\
\text { social work }\end{array}$ & & & & $.450 * * 8$ & $.434^{* 8 *}$ \\
\hline \multicolumn{6}{|l|}{ Interaction age $x$ immigrant generation } \\
\hline $35-49 \mathrm{x}$ first generation & & & & & $1.542^{* * *}$ \\
\hline $35-49 \mathrm{x}$ second generation & & & & & $1.604^{* * *}$ \\
\hline $50-59 \times$ first generation [SU1st_50-59] & & & & & $.832^{* *}$ \\
\hline $50-59 \mathrm{x}$ second generation & & & & & $.665^{* * *}$ \\
\hline Constant & $.075^{* * *}$ & $.080^{* * *}$ & $.081^{* * *}$ & $.023^{* * *}$ & $.023^{* * *}$ \\
\hline R square & .10 & .11 & .11 & .38 & .38 \\
\hline
\end{tabular}

Source: Own calculations based on Estonian Labor Force Survey 2011-13.

Referengefificant at level .001; ** significant at level .01

AASLAND, A and Fløtten T (2001) 'Ethnicity and social exclusion in Estonia and Latvia',Europe-Asia Studies, Vol. 53, No. 7, p. 1023-1049.

ALBA, R (1988) Cohorts and the Dynamics of Ethnic Change. p. 211-28 in RileyM F (Ed) Social Structures and Human Lives, Newbury Park, CA: Sage.

ALBA R, Jimenez T R and Marrow H B (2014) 'Mexican Americans as a Paradigm for Contemporary Intra-group Heterogeneity', Ethnic and Racial Studies, Vol. 37 No. 3, p. 446-466.

ALBA R and Nee V (2003) Remaking the American Mainstream: Assimilation and Contemporary Immigration, Cambridge: Harvard University Press. [doi:10.1080/01419870.2013.786111] 
ALBA R and Waters M C (2011) Dimensions of Second-Generation Incorporation. Pp. 1-28 in Alba R and Waters M C (Eds.) The next generation: Immigrant youth in a comparative perspective, New York: New York University Press.

BOHRT M A and Itzigsohn J (2015) 'Class, Race, and the Incorporation of latinos/as: Testing the Stratified Ethnoracial Incorporation Approach', Sociology of Race and Ethnicity, Vol. 1, No. 3, p. 360-377.

[doi:10.4159/9780674020115]

CENSUS SNAPSHOTS (2013) Tallinn: Statistics Estonia.

CHISWICK B R (2002) 'Immigrant earnings: language skills, linguistic concentrations and the business cycle', Journal of Population Economics, Vol. 15, No. 1, p. 31-57. [doi:10.18574/nyu/9780814707425.003.0001]

CRUL M and Mollenkopf J (2012) The Second Generation. Pp. 3-25 in Crul M and Mollenkopf J (Eds.)The Changing Face of World Cities, New York: Russell Sage Foundation.

CRUL M and Vermeulen H (2003) 'The second generation in Europe', International Migration Review, Vol. 37, No. 4, p. 965-986. [doi:10.1177/2332649215570760]

CRUL M and Schneider J (2010) 'Comparative integration context theory: participation and belonging in new diverse European cities', Ethnic and Racial Studies, Vol. 33, No.7, p. 1249-1268.

CRUL M and Schneider J (2012) Conclusions and implications. The integration context matters. p. 375-405 in Crul M, Schneider J and Lelie F (Eds.) The European Second Generation Compared: Does the Integration Context Matter?, Amsterdam: Amsterdam University Press.

CRUL M and Heering L (2008) The Position of the Turkish and Maroccan Second Generation in Amsterdam and Rotterdam, Amsterdam: Amsterdam University Press.

FONER, N and Lucassen, L (2012) Legacies of the Past. p. 26-43 in Crul M, Mollenkopf J (Eds.) The Changing Face of World Cities, New York: Russell Sage Foundation.[doi:10.1007/PL00003838]

FRIEDBERG R M (2000) 'You can't take it with you: Immigrant assimilation and the portability of human capital', Journal of Labour Economics, Vol. 18, p. 221-251.

GORDON, M (1964) Assimilation in American Life, New York: Oxford University Press.

HALLIK K (2002) Nationalising policies and integration challenges. Pp. 65-88 in Lauristin M and HeidmetsM (Eds.) The Challenges of the Russian Minority: Emerging Multicultural Democracy in Estonia Tartu: Tartu University Press.

HAZANS M (2010) Ethnic minorities in Latvian labour market, 1997-2009: Outcomes, integration drivers and barriers, p. 125-158 in Muižnieks N (Ed) How integrated is Latvian Society? An Audit of Achievements, Failures and Challenges, Riga, Latvia: University of Latvia Press. [doi:10.1111/j.17477379.2003.tb00166.x]

HAZANS M, Trapeznikova I and Rastrigina O (2008) 'Ethnic and parental effects on schooling outcomes before and during the transition: Evidence from the Baltic countries', Journal of Population Economics, Vol. 21, No. 3, p. 719-749.

HEATH A and Cheung S Y (2007a) The comparative study of ethnic minority disadvantage. p. 1-44 in Heath A F and Cheung S Y (Eds.) Unequal chances: Ethnic minorities in western labor market Oxford: Oxford University Press. [doi:10.1080/01419871003624068]

HEATH A F and Cheung S Y (Eds.) (2007b)Unequal Chances: Ethnic Minorities in Western Labour Markets, Oxford/New York: Oxford University Press.

HEATH A F, Rothon C and Kilpi E (2008) 'The second generation in Western Europe: Education, unemployment, and occupational attainment', Annual Review of Sociology, Vol. 34, p. 211-235.

KENNEDY M (2002) Cultural Formations of Postcommunism, Minneapolis: University of Minnesota Press.

KOGAN I (2006) 'Labor markets and economic incorporation among recent immigrants in Europe',Social Forces, Vol. 85, No. 2, p. 697-721. [doi:10.5117/9789089640611] 
KULU H (2001) 'Sõjajärgne sisseränne Eestisse võrdlevas perspektiivis' [Postwar Immigration to Estonia in Comparative Perspective], Akadeemia, Vol. 11, No. 152, p. 2379-2395.

KUZIO T (2002) 'History, memory and nation building in the post-Soviet colonial space',Nationalities Papers, Vol. 30, No.2, p. 241-264.

LESSARD-PHILIPS L, Fibbi R and Wanner P (2012) Assessing the labor market position and the determinants for the second generation. p. 165-224 in Crul M, Schneider J and Lelie F (Eds.) The European Second Generation Compared: Does the Integration Context Matter?, Amsterdam: Amsterdam University Press.

LINDEMANN K (2011) Explaining different returns from human capital in the labor market. Pp. 93-118 in Vetik R and Helemäe J (Eds.) The Russian Second Generation in Tallinn and Kohtla-Järve: The TIES Study in Estonia, Amsterdam: University of Amsterdam. [doi:10.1086/209957]

LINDEMANN K (2013) Structural integration of young Russian-speakers in post-Soviet contexts: educational attainment and transition to the labour market, Tallinn: Tallinn University.

LINDEMANN, K and E. Saar E (2011) Ethnic inequalities in education. p. 59-91 in Vetik R and Helemäe J (Eds.) The Russian Second Generation in Tallinn and Kohtla-Järve: The TIES Study in Estonia Amsterdam: University of Amsterdam.

LINDEMANN K and Saar E (2012) 'Ethnic inequalities in education: second-generation Russians in Estonia', Ethnic and Racial Studies, Vol. 35, No.11, p. 1974-1998.

LINDEMANN K and Kogan I (2013) 'The Role on Language Resources in Labour Market Entry: Comparing Estonia and Ukraine', Journal of Ethnic and Migration Studies Vol. 39, No. 1, p. 105-123.

METTAM C W and Williams S W (2001.) 'A colonial perspective on population migration in Soviet Estonia', Journal of Ethnic and Migration Studies, Vol. 27, No. 1, p. 133-150.

OECD (2007) Review of tertiary education in Estonia, Paris: OECD.

OECD (2013) Immigrant and foreign population, in OECD FACTBOOK 2013: Economic, Environmental and Social Statistics, Paris: OECD.

OJAMÄE L and Paadam K (2011) Housing conditions and neighbourhood satisfaction. Pp. 143-64 in Vetik R and Helemäe J (Eds.) The Russian Second Generation in Tallinn and Kohtla-Järve: The TIES Study in Estonia, Amsterdam: University of Amsterdam. [doi:10.1007/s00148-007-0134-y]

PETTAI V and Hallik K (2002) 'Understanding processes of ethnic control: segmentation, dependency and cooptation in post-communist Estonia', Nations and Nationalism, Vol. 8, No. 4, p. 505-529.

PHALET K and Heath A F (2010) 'From ethnic boundaries to ethnic penalties: Urban economies and the Turkish second generation', American Behavioral Scientist, Vol. 53, No.12, p. 1824-1850. [doi:10.5871/bacad/9780197263860.003.0001]

PHALET K and Heath A F (2011) Ethnic Community, Urban Economy, and Second-Generation Attainment. p. 135-165 in Alba R and Waters M C (Eds.) The next generation: Immigrant youth in a comparative perspective, New York: New York University Press.

PORTES A and DeWind J (2004) 'A Cross-Atlantic Dialogue: The progress of Research and Theory in the Study of International Migration', International Migration Review, Vol. 28, No. 5, p. 828-851.

PORTES A and Zhou M (1993) 'The new second generation: Segmented assimilation and its Variants', The Annals, Vol. 530, No. 1, p. 74-96.

PORTES A and Rumbaut R G (2001) Legacies: The Story of the Immigrant Second Generation, Berkeley: University of California Press. [doi:10.1146/annurev.soc.34.040507.134728]

RANNUT M (2008) 'Estonianization Efforts Post-Independence', International Journal of Bilingual Education and Bilingualism, Vol. 11, No. 3, p. 423-439.

REITZ J G and Somerville K (2004) 'Institutional Change and Emerging Cohorts of "New" Immigrant Second Generation: Implications for the Integration of Racial Minorities in Canada', Journal of International Migration and Integration, Vol. 5, No. 4, p. 385-415. 
SAAR E and Titma M (1992) MigratsionsstrÖme in sowjetisierten Baltikum and ihre Nachwirkung auf die baltischen Staaten nach Wiederherstellung der Selbsständigkeit. Berichte des Bundesinstituts für Ostwissenschaftliche and internatinale Studien No. 9.

SILBERMAN R, Alba R and Fournier I (2007) 'Segmented assimilation in France? Discrimination in the labour market against the second generation', Ethnic and Racial Studies, Vol. 30, No. 1, p. 1-27. [doi:10.1353/sof.2007.0014]

THOMSON M and Crul M (2007) 'The Second Generation in Europe and the United States: How is the Transatlantic Debate Relevant for Further Research on the European Second Generation?' Journal of Ethnic and Migration Studies, Vol. 33, No. 7, p. 1025-1042.

VAN TUBERGEN F (2006) Immigrant Integration: A Cross-National Study, New York: LFB Scholarly Publishing.

VERMEULEN H (2012) Segmented assimilation and cross-national comparative research on the integration of immigrants and their children. p. 71-87 in Schneider $\mathrm{J}$ and Crul M (Eds.) Theorising Integration and Assimilation, London and New York: Routledge.

VETIK R (1993) 'Ethnic conflict and accommodation in post-communist Estonia', Journal of Peace Research, Vol. 30, No. 3, p. 271-280. [doi:10.1080/00905990220140649]

VETIK R and Helemäe J (2011a) Introduction. p. 13-25 in Vetik R and Helemäe J (Eds.)The Russian Second Generation in Tallinn and Kohtla-Järve: The TIES Study in Estonia, Amsterdam: University of Amsterdam.

VETIK R and Helemäe J (Eds.) (2011b) The Russian Second Generation in Tallinn and Kohtla-Järve: The TIES Study in Estonia, Amsterdam: University of Amsterdam.

VETIK R and Kionka R (1996) Estonia and Estonians. p. 129-146 in Smith G (Ed.)The nationalities question in the post-Soviet states, London: Longman.

VÖÖRMANN R and Helemäe J (2003) 'Ethnic Relations in Estonia's Business Community',Ethnicities, Vol. 3, No. 4, p. 509-530.

WATERS N C and Jimenez T R (2005) 'Assessing immigrant assimilation: New empirical and theoretical challenges', Annual Review of Sociology, Vol. 31, p. 105-125.

WATERS M C, Tran V C, Kasinitz P and Mollenkopf J H (2012) Segmented assimilation revisited: types of acculturation and socioeconomic mobility in young adulthood. p. 25-50 in m Schneider $\mathrm{J}$ and Crul M (Eds.) Theorising Integration and Assimilation, London and New York: Routledge.

WESTIN C (2003) 'Young people of migrant origin in Sweden', International Migration Review, Vol. 37, No. 4, p. 987-1010.

ZASLAVSKY V (1992) The Evolution of Separatism in Soviet Union under Gorbachev, in Lapidus G W (Eds.) From Union to Commonwealth: Nationalism and Separatism in the Soviet Republics, New York: Cambridge University Press. 